\title{
Education And Small Business Growth: A Gender Perspective Of Two Divergent Provinces In South Africa
}

\author{
Ricardo Martin Peters, University of the Western Cape, South Africa \\ Garth van Gensen, University of the Western Cape, South Africa \\ Eslyn Bleighnaul Hugh Isaacs, University of the Western Cape, South Africa \\ Mark Jonathan Botha, University of the Western Cape, South Africa \\ Visvanathan Naicker, University of South Africa, South Africa
}

\begin{abstract}
The article attempts to identify whether the level of education and gender has an impact on the business growth of SMMEs in a developing economy. The study furthermore looks at the contribution made by the SMME sector from a spatial perspective. The Western Cape is seen as a more affluent province and a bigger contributor to the country's GDP as opposed to KwaZuluNatal, which comprises of the former province of Natal and the Zululand homelands.

Entrepreneurship can be considered as one of the means of creating an enabling environment conducive to reducing poverty, stimulating economic growth, and creating employment opportunities, particularly in a South African context. Hence, activities in the SMME sector are often considered to be the bedrock of an economy and a key driver of growth and development. This holds most true for women assuming the role of entrepreneur, especially in developing countries. This study aims to explore and test this delicate relationship between women entrepreneurs and SMME sustainability, and to conduct empirical investigations into high-density SMME operations in two South African provinces.
\end{abstract}

Survey data were collected from SMME owners/managers in the Western Cape and KwaZuluNatal provinces of South Africa. In building on previous academic literature on SMME sustainability and women in business, various measures are developed and tested for reliability and validity. The study is cross-sectional in design, making use of trained fieldworkers to administer face-to-face surveys to a diverse set of SMMEs. A structured questionnaire was used to collect data from 465 owners/managers in the two provinces. The findings show (i) a positive relationship between a business owner's/manager's level of education and business growth, (ii) no correlation between a business owner's/manager's education and employment, and (iii) no relationship between gender and business growth. The findings of the study can benefit the South African Government in directing policy, SMME owners, educators and women in business by increasing awareness of the nature of sustainable SMMEs, and the effect of operational skills, gender and education on the development thereof.

This study focuses on the growing sector of women in business and the impact of education in SMMEs linked toward business sustainability. A contribution is made toward theory development through empirical research.

Keywords: Entrepreneurship; Educational Level; Business Success Factors; SMMEs; Republic of South Africa

\section{INTRODUCTION}

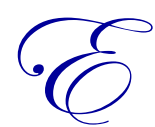

conomic transformation in the South African context is a business necessity due to apartheid polices implemented by the former Nationalist Party government. The resulting social and economic repression led to the expropriation of Black-owned property under the Land Act and the disempowerment of one 
race over another (RSA, 1996). Apartheid excluded many citizens from participating in the economy on the basis of race. This, in turn, created a situation where a significant stake in the country's economic wealth creation was historically - and still is currently - held by the top $10 \%$ of income earners who are predominantly White citizens. The democratically elected government tried to rectify this imbalance by creating an enabling environment through policies, strategies, and frameworks and by replacing disenabling acts to allow small, medium, and micro enterprises (SMMEs) to grow and prosper. This sector, according to the Department of Trade and Industry (DTI), has the potential to improve job creation opportunities and wealth distribution necessities (DTI, 1995). SMME has been an important research field among academics for a considerable length of time. In developing economies, such as South Africa, SMMEs are viewed as engines of economic progress, helping to create job opportunities and contributing toward the correction of past social injustices (Gurol \& Atsan, 2006). With the South African economy being in transition for over eighteen years into the new democracy, SMMEs are accounting for an increasingly greater proportion of economic activity (Peters, 2009).

It is accepted worldwide that the development and growth of SMMEs can play an important role in job creation, social stability, and economic welfare. It is for these reasons that the proliferation of small businesses in South Africa is encouraged as being beneficial. This is particularly imperative considering the fact that the official unemployment rate in South Africa stands at 25\%, with one of the most skewed Gini coefficients in the world (Stats SA, 2012). The World Bank (2006) asserts that South Africa is characterised as a developing country, whilst Kirstein (2006) refers to it as a two-tiered economy (first and second economies). The notion of two economies in South Africa is a metaphor implying that while part of the South African economy is cutting-edge, globalised, and comparable to that of any developed country, another part is marginalised and underdeveloped. Kirstein (2006) further argues that despite government's claims that there has been some progress in development since the democratic elections in 1994, these claims cannot be substantiated by any real facts. The number of people trapped in the second (marginalised and underdeveloped) economy continues to rise, contributing to the uneven distribution of wealth, high levels of poverty, and unemployment (World Bank, 2008). The South African government contends that the challenges associated with high levels of poverty, income inequality and unemployment can be addressed through job creation and education, paying special attention to previously disenfranchised groups or previously disadvantaged individuals (PDIs).

Although a lack of entrepreneurial knowledge and business management skills was identified, as many as 18 years ago, as being the reason for business failure (Scarborough \& Zimmerer, 1996), this is still being observed today. Furthermore, Yanta (2001) rightfully states that low levels of education and poor business skills are some of the factors leading to the lack of capacity and poor business efficiency among SMMEs. Empirical observations in South Africa, as supported by Sheppard, Douglas, and Shanley (2000), reveal that many entrepreneurs venture into their own businesses despite being unaware of the numerous key dimensions involved.

Women of all races, irrespective of colour or creed, are viewed as PDIs who have been subjected to discrimination and have consequently faced numerous challenges in terms of employment limitations (e.g., "glass ceiling"), business failures, and financial hardships. It is for this reason that the focus of this study is gender-biased.

\section{PROBLEM STATEMENT AND RESEARCH QUESTIONS}

The aim of this study is to examine the educational levels of the SMME owners/managers involved and the relationship between education and business growth from a gender perspective in the provinces of the Western Cape (WC) and KwaZulu-Natal (KZN). Therefore, this study tests the following propositions:

$\mathbf{P}_{1}$ : $\quad$ Growth of a business is independent of gender.

$\mathbf{P}_{2}$ : There is a relationship between level of education and labour growth in SMMEs.

\section{LITERATURE REVIEW}

Guzman (1994) states that the entrepreneurial quality of a business owner is a critical factor in overcoming barriers to survival and achieving sustainable growth in the SMME sector and proposes that a combination of formal and on-the-job training may be seen as one of the key contributors to enhance entrepreneurial quality and make a 
positive contribution when it comes to laying the foundation for success. Education is therefore thought to improve the intrinsic motivation and energising behaviours (Guzman \& Santos, 2001), and the more enterprise education an individual receives, the greater the chances of entrepreneurial success (Scott \& Gibb, 1986). Entrepreneurship is an important source of employment for women across the world, giving them the freedom and flexibility to manage their own business and personal lives. Through their involvement in business, they contribute positively to the growth of a country (Arenius \& Minniti, 2005). Very little evidence can be found on the relationship between education and entrepreneurship (Blanchflower \& Oswald, 2004), although basic literacy seems to be a requirement for both men and women when starting a new business (Reynolds, Williams, \& Savage, 1994). Gender differences in entrepreneurial activity are well documented in the literature (Gatewood, Carter, Brush, Greene, \& Hart, 2003). A study by Acs, Arenius, Hay, and Minniti (2005) revealed that almost twice as many men as women become entrepreneurs and that these differences are consistent across several countries. According to De Bruin, Brush, and Welter (2006), the number of female entrepreneurs has increased dramatically; however, the increase in business growth may or may not be influenced by gender. More specifically, Carter and Rosa (1998) and Marlow and Patton (2005) argue that the concepts of gender and entrepreneurship limit women's ability to accrue social, cultural, human and financial capital as well as to generate personal savings and establish credit histories attractive to resource providers, thereby impacting on the growth of the business (Cliff, 1998). Loan officers were found by Alsos, Isaksen, and Ljunggren (2006) to perceive female entrepreneurs as being different from male entrepreneurs (with women being less likely to have access to mortgage possibilities, thereby acquiring debt capital for their respective businesses). Given the above scenario, it is therefore not surprising that undercapitalisation or lack of adequate funding (Brush, Carter, Gatewood, Greene, \& Hart, 2004b) has been identified as a major cause of slower growth and poorer performance in women-owned businesses (Carter, 2000; Marlow \& Patton, 2005). These performance indicators include revenues and employment, for example.

It is clear that entrepreneurship can be approached from a feminist or masculinity perspective. The feminist perspective can further be approached from a liberal or social perspective. According to Brush (1997) and Carter and Allen (1997), liberal feminism is occasionally called the situational perspective and suggests that men and women begin with equal potential and that differences manifest as a result of systematic inequalities in education, employment opportunities, and experience. Women entrepreneurs with a higher level of education express greater interest in growing their enterprises (Welter, 2006). Isaksen and Kolvereid (2005) found that women business founders have lower growth ambitions, as well as fewer total assets and lower levels of equity than men. They found women-owned businesses to achieve lower sales levels than those owned by men, but few differences were detected in terms of the perceptions and behaviours related to obtaining financial resources for developing and growing their businesses. Female entrepreneurship is now considered one of the major sources of growth, employment, and innovation. Women in business often claim to be discriminated against in both overt and subtle ways. Therefore, from a liberal feminist theory perspective, women given the same opportunities will perform just as well as their male counterparts and, in some cases, even better (Kalleberg \& Leicht, 1991). Unfortunately, women face more educational, family, and workplace challenges than their male counterparts. Social feminists hold the view that males and females are different, as they are exposed to different socialisation processes that shape their thinking and rationalisation (Fischer, Reuber, \& Dyke, 1993) and which could have an impact on their management of a business and its ultimate performance. While feminism provides one perspective on gender differences in entrepreneurship, some scholars have criticised this approach. According to Belenky, Clinchy, Goldberger, and Tarule (1986), "If and when scientists turn to the study of women, they typically look for ways in which they conform to or diverge from patterns found in the study of men." Moreover, Brush (1992) describes such a rationale as "entrepreneurs-as-male," where women business owners are typically described as having "less," "smaller," or "fewer" (e.g., management experience, education, access to resources, and risk propensity). Thus, examining the influence of gender by comparing female to male business owners fails to recognise that gender influences reside not only in the owner, but also in the social structure, education, and politics involved.

Since 1995, the South African government has developed and implemented various policy interventions. Some of them were successful but, in the main, they failed to yield a meaningful contribution toward economic development for all of the country's citizens, especially those classified as previously disadvantaged. Most of these interventions are related to access to financial resources. Jackson (2004) argues that access to micro credit is not the primary constraint to small enterprise development, but, instead, there is an increasing shift toward recognition of the critical importance of nonfinancial constraints, such as lack of information and lack of management and business 
skills. It is through the delivery of education and business training that these nonfinancial constraints can be addressed. Radipere and Van Scheers (2005) thus recommend that education and training should focus on administrative, financial management, and marketing skills. Marketing, as part of business training, constitutes an important part of the effort to promote SMMEs. It is thus not surprising that the South African government has now embarked on a mission to support training for SMMEs, focusing on basic literacy, numeracy, and communication skills to improve particularly the skills of business owners in the micro sector. Other findings reveal that women seem to be more concerned about the risks associated with fast-paced growth and tend to deliberately adopt a steady rate of expansion (personal considerations appear to override economic considerations in the business expansion decision). Many women express the desire to not let growth "get out of control," which also has important implications for financial capital providers. This managed approach to business expansion may yield ventures that are able to outlast those headed by entrepreneurs pursuing more risky, high-growth strategies.

A study conducted in India by Ghosh (2002) found that a more direct single-domain condition, such as a lack of technical skills development in schools or lack of vocational training, is contributing to the subordination of women with poorer socio-economic means. He found that family or social norms often prevent girls from participating in skills-based education. In South Africa, a lack of specific skills can prevent many women from starting their own businesses. The literature on business growth is extensive, but researchers argue that this topic deserves greater attention due to its importance in job creation and socio-economic development (Barringer, Jones, \& Neubaum, 2005; Moreno \& Casillas, 2007). While it is not the purpose of this study to review this broad area in great depth, it is useful to summarise some of the key factors that consistently emerge before narrowing the focus to SMME growth.

Growth may be measured by the achievement of rising sales levels over a defined period and/or growth in employment (Garnsey, Stam, \& Heffernan, 2006; Moreno \& Casillas, 2007). While sales volume is a common growth measure, it can be argued that sales are dependent on external factors such as inflation and exchange rates. Employment growth, on the other hand, is not as dependent on such external factors (Delmar, Davidsson, \& Gartner, 2003) and is therefore a better measure of business growth. Research has also shown that SMME growth and competitiveness is constrained by a lack of access to financing (Berger \& Udell, 2006; Ogujiuba, Ohuche, \& Adenuga (2004). SMMEs, it seems, live in a world where growth is the normative expectation. However, some SMMEs are unable to grow due to informational asymmetry, which results in a finance gap contributing to the inability to grow (Vos, Yeh, Carter, \& Tagg, 2007). Notwithstanding, many SMMEs are growing beyond the size that informal sources of finance can support and, therefore, institutional credit is the only feasible option for financing growth (Wattanapruttipaisan, 2003).

As previously mentioned, most SMMEs rely on internal sources of funds in their early years of operation. As SMMEs grow in size and age, they ought to have better access to external funds. Unlike public companies, small businesses are not required to provide private information to prospective investors, creditors, and customers (Ang, 1992). This absence of transparent disclosure results in less credible signals being sent to venture capitalists, banks, or trade creditors, implying that SMMEs have limited access to external funds due to informational asymmetries and thereby impeding their accumulation of revenue and assets, as well as their potential growth. The literature reveals that most SMMEs do not opt for rapid growth and that most SMME owners prefer to retain control by not applying for external capital (Curran, Bolton, \& Britain, 1986; Jarvis, 2000; Vos et al., 2007).

In relation to business growth, service businesses, in general, have received little attention (De Jong \& Vermeulen, 2006). They may have different growth patterns to manufacturing businesses and, even within the service sector, different types of businesses tend to have lower growth aspirations than do entrepreneurs who establish manufacturing businesses (Kolvereid, 1992; Wilson \& Morris, 2000). This is potential concern for a developing country, like South Africa, which is dependent on the service sector as the largest sector in the country, currently contributing more than 60\% to Gross Domestic Product (GDP).

Gender also appears to impact on growth. Stoner, Hartman, and Arora (1990) argue that women-owned businesses are especially affected by conflicts between home and family demands and these conflicts may have deliberate or inadvertent implications for growth. It has been suggested that a primary hurdle faced by women aspiring to develop high-growth businesses is the inability to obtain financing (Morris, Miyasaki, Watters, \& 
Coombes, 2006). Female entrepreneurs tend to start retail and service businesses - some with growth potential, but others without. However, those with high growth potential are curtailed by a lack of finances or access to financial resources, with the result that some of these SMMEs remain small (Catley \& Hamilton, 1998; Kalleberg \& Leicht, 1991). Although some retail and service businesses can be started with a limited amount of capital, financial resources, or access thereto, remain crucial for business survival and growth. Undercapitalisation is associated with lower growth (Carter, 2000; Marlow \& Patton, 2005), while adequate or sufficient funding is associated with growth (Brush, Carter, Gatewood, Greene, \& Hart, 2004a).

Earlier studies (Cooper, Gimeno-Gascon, \& Woo, 1994; Fischer et al., 1993) showed that women-owned businesses grow less quickly than those owned by men. A number of authors have begun to challenge the idea that the growth of an organisation is a naturally occurring phenomenon, proposing instead that expansion is at least partially determined by the entrepreneur's motivations and intentions for the business (Bird \& Jelinek, 1988; Cooper, 1993; Kolvereid, 1992). Several studies have found that many women-owned businesses are kept deliberately small, thereby limiting business growth (Cliff, 1998; Goffee \& Scase, 1985; Kaplan, 1988; LeeGosselin \& Grisé, 1990), or have conservative growth expectations (Belcourt, Burke, \& Lee-Gosselin, 1991; Chaganti, 1986). According to Kesper (2001), most new SMMEs in South Africa lack profitability and growth and many do not report a profit or an increase in turnover. Their constraints include poor micro-economic conditions, the influx of price-competitive imports into the domestic market, wage increases that erode the price competitiveness of SMMEs, the sales of SMMEs being primarily concentrated on the local markets, and high input costs, especially transport and labour costs.

Over the years, there has been some research into the gender of business owners and how this affects their access to debt capital (Alsos et al., 2006; Carter, Shaw, Wilson \& Lam, 2006; Fabowale, Orser, \& Riding, 1994), but there has been little research related to gender and business growth. Knowledge on business funding in the start-up phase and during early business growth is scarce, particularly from a gender perspective (Alsos et al., 2006). According to the literature, education is seen to be associated with business growth. It is therefore the intention of this study to establish whether there is relationship between education and growth and whether gender is related to business growth.

\section{DEMARCATION OF THE STUDY}

As mentioned earlier, the focus is on gender, education, and growth. Furthermore, the study is limited to SMMEs operating in the provinces of the Western Cape (WC) and KwaZulu-Natal (KZN). The reason for choosing these two provinces is outlined below.

\section{Comparing the Western Cape to KwaZulu-Natal: Why?}

Almost 19 years into the implementation of the SMME development strategies, South Africa's formal employment problem remains largely unchanged. Many researchers, including Kesper (2001), Chalera (2007), and Peters (2009), argue that this dilemma can be attributed to an array of ineffective policy measures. A critical flaw identified in government's national strategy, and persisting to this day, is its failure to segment the SMME market into small- and medium-sized businesses and survivalist and micro-sized enterprises. This strategy requires a core specific targeted approach as opposed to the more generic strategy adopted initially by government. Further to this problem, and as a direct result of apartheid, is the location of racially-divided businesses and residential areas in South Africa. Cities and towns are not planned to cater to the poor, with long travelling distances to work and poor access to businesses and other services. Poor and rich areas have vastly different levels of service and the proliferation of sprawling informal settlements in stark contrast to the contained residential areas make costeffective service delivery very difficult. Most major industries are located near cities, with very few large production facilities located in rural areas or close to areas inhabited by PDIs (such as the former homelands or the aforementioned informal settlements). From a spatial perspective, government's support initiatives are mainly located and geared toward servicing the major industrial centres in Gauteng and the Western Cape. A further consequence of apartheid is the location of previously disadvantaged communities in particularly Black African areas that were purposefully situated outside and far removed from towns and city centres and, more importantly, industrial hubs. This apartheid-era "spatial development plan" gave rise to serious issues surrounding job creation 
and poverty alleviation. To exacerbate matters, under apartheid's spatial planning, heavy emphasis was placed on top-down regional policy interventions designed to promote industrial decentralisation in the country's peripheral 'homelands' or 'Bantustan regions' (Peters, 2009). Today there are still many small and rural towns with no heavy industries that can offer meaningful employment opportunities to the people in the surrounding areas.

The Western Cape is better developed spatially and is also more affluent than KwaZulu-Natal, which is a prime microcosm of the so-called uneven distribution of wealth. KZN was formed through a merger between the former province of Natal and the former homelands, including Zululand. The more "Black" Zululand was characterised by extreme poverty, while the more "White" Natal was characterised by more privileged Whites. Within this context, both the state and private organisations investigated and experimented with a variety of employment-generating strategies, finding it necessary to focus on those strategies that would foster economic development from a spatial perspective. Government established a range of financing mechanisms, including the Local Economic Development (LED) Fund, Municipal Infrastructure Grant, Integrated Sustainable Rural Development Programme, and Urban Renewal Programme. Overall, whilst the country lacks an embracing LED policy document, and many of the above-mentioned interventions are not specifically named as 'pro-poor' or 'prorural' strategies, what it does have in place are various laws, policies, and funding mechanisms which, though perhaps not always totally successful in terms of job creation and poverty alleviation, have nevertheless created a clearly defined framework for pro-poor LED intervention and support. However, this effort has not been effective in reducing unemployment and eradicating or reducing poverty. Instead, this resulted in the creation of an extremely rich class of Blacks with disproportionate remunerative rewards and an ever-expanding poor mass of (mainly) Black Africans. The majority of small towns and rural areas need targeted support initiatives to alleviate poverty and boost economic growth.

In a study conducted by Reynolds, Bygrave, Autio, Cox, and Hay (2003), Gauteng, KwaZulu-Natal, and the Western Cape were found to be the most entrepreneurial regions in South Africa. On the other hand, the Human Sciences Research Council (HSRC) identified KZN as having the largest poverty gap of all the country's provinces. The poverty gap is the measure of required annual income transfer to all poor households required to alleviate poverty. In 2004, the gap for KZN was R 18 billion and growing (Fenske, 2004).

\section{RESEARCH METHODOLOGY}

This study is based on the quantitative approach, using a survey method; namely, a structured and validated questionnaire. The sample comprised 1,652 SMME owners/managers from KwaZulu-Natal and the Western Cape, from which 930 completed and usable questionnaires were received. An equal number of responses (i.e., 465) were received from both KZN and WC, giving a response rate of 56.3\%. Personal interviews were used to collect the relevant data using a structured questionnaire survey.

The study was cross-sectional in design and relied on trained field workers to administer surveys for data collection. A field manager was appointed to control the collection of data due to the vast geographical area and different provinces involved. A fortnightly return schedule was implemented for field workers to hand in the completed questionnaires. The researchers conducted training sessions to ensure that correct data were captured and a compulsory weekly meeting with the field manager was conducted to ensure quality control. A process of checking the questionnaires was maintained throughout the duration of the survey to ensure a decent response rate $(56.3 \%)$ and usable data for the survey.

Following the data-collection stage, each questionnaire was checked for errors, legibility, and consistency to ensure completeness and readability of the data. Thereafter, the data were captured onto SPSS software version 20.0. A descriptive and chi-square analysis was used to present the results. Chi-square analysis was used to test the hypothesis for associations between the variables and to explain the variance in business growth between the provinces of KZN and WC. In order to obtain a sample with suitable characteristics during the survey, the following criteria were taken into consideration: 1) The enterprise had to have been in existence for more than one year and 2) the enterprise had to comply with the amended Small Business Act's definition of an SMME in terms of number of employees and turnover. 


\section{FINDINGS}

\section{Demographics}

The owner's profile includes gender, age, and education, whilst that of the business is based on age, sector, and legal form of ownership.

As shown in Table 1, the sample for WC was composed of $70.0 \%$ males and $30.0 \%$ females while for $\mathrm{KZN}$, it was $61.0 \%$ males and $39.0 \%$ females. As this was a random sample, it indicates fewer female business owners than male.

Table 1: Composition of Sample - Western Cape (WC) and KwaZulu-Natal (KZN) Gender of Business Owners Interviewed

\begin{tabular}{|l|c|c|c|c|}
\hline \multirow{2}{*}{} & \multicolumn{2}{|c|}{ WC } & \multicolumn{2}{c|}{ KZN } \\
\cline { 2 - 5 } & Frequency & Percent & Frequency & Percent \\
\hline Male & 326 & $70 \%$ & 284 & $61 \%$ \\
\hline Female & 139 & $30 \%$ & 181 & $39 \%$ \\
\hline Total & $\mathbf{4 6 5}$ & $\mathbf{1 0 0 . 0 \%}$ & $\mathbf{4 6 5}$ & $\mathbf{1 0 0 \%}$ \\
\hline
\end{tabular}

As noted in Table 2, 48.2\% of WC and $53.1 \%$ of KZN business owners were in the middle-aged category (40 to 49 years). Only $6.9 \%$ of WC and $0.4 \%$ of KZN owners were in the age group 17 to 29 years.

Table 2: Age category of Business Owners Interviewed

\begin{tabular}{|l|c|c|c|c|}
\hline \multirow{2}{*}{} & \multicolumn{2}{|c|}{ WC } & \multicolumn{2}{c|}{ KZN } \\
\cline { 2 - 5 } & Range & Percent & Range & Percent \\
\hline $\mathbf{1 7}-\mathbf{2 9}$ & 32 & $6.9 \%$ & 2 & $0.4 \%$ \\
\hline $\mathbf{3 0}-\mathbf{3 9}$ & 101 & $21.7 \%$ & 115 & $24.7 \%$ \\
\hline $\mathbf{4 0}-\mathbf{4 9}$ & 224 & $48.2 \%$ & 247 & $53.1 \%$ \\
\hline $\mathbf{5 0}-\mathbf{5 9}$ & 98 & $21.1 \%$ & 88 & $19.9 \%$ \\
\hline $\mathbf{6 0}$ and over & 10 & $2.1 \%$ & 13 & $2.7 \%$ \\
\hline Total & $\mathbf{4 6 5}$ & $\mathbf{1 0 0 . 0 \%}$ & $\mathbf{4 6 5}$ & $\mathbf{1 0 0 . 0 \%}$ \\
\hline
\end{tabular}

According to Table 3, 29.8\% of WC respondents were female, as opposed to $39 \%$ in KZN. The majority of women $(14.1 \%$ in WC and $17.0 \%$ in $\mathrm{KZN})$ fell in the age group of $30-39$ years. This is the only group showing a significant difference between males and females $(\mathrm{p}<0: 05)$.

Table 3: Age of Business Owners Interviewed (Gender Perspective)

\begin{tabular}{|l|c|c|c|c|c|c|}
\hline & \multicolumn{3}{|c|}{ WC } & \multicolumn{2}{c|}{ KZN } \\
\cline { 2 - 7 } & Male & Female & Total & Male & Female & Total \\
\hline $\mathbf{1 7}-\mathbf{2 9}$ & $18: 3.9 \%$ & $14: 3.0 \%$ & $32: 6.9 \%$ & $0.0 \%$ & $0.4 \%$ & $2: 0.4 \%$ \\
\hline $\mathbf{3 0}-\mathbf{3 9}$ & $35: 7.6 \%$ & $66: 14.1 \%$ & $101: 21.7 \%$ & $7.7 \%$ & $17.0 \%$ & $115: 24.7 \%$ \\
\hline $\mathbf{4 0}-\mathbf{4 9}$ & $174: 37.5 \%$ & $50: 10.7 \%$ & $224: 48.2 \%$ & $33.4 \%$ & $19.7 \%$ & $247: 53.1 \%$ \\
\hline $\mathbf{5 0}-\mathbf{5 9}$ & $68: 14.6 \%$ & $30: 6.5 \%$ & $98: 21.1 \%$ & $17.0 \%$ & $1.9 \%$ & $88: 18.9 \%$ \\
\hline $\mathbf{6 0}$ and over & $6: 1.3 \%$ & $4: 0.9 \%$ & $10: 2.1 \%$ & $2.9 \%$ & $0.0 \%$ & $13: 2.9 \%$ \\
\hline Total & $\mathbf{3 0 1 : 7 0 . 2 \%}$ & $\mathbf{1 6 4 : 2 9 . 8 \%}$ & $\mathbf{1 0 0 . 0 \%}$ & $\mathbf{6 1 . 0 \%}$ & $\mathbf{3 9 . 0 \%}$ & $\mathbf{1 0 0 . 0 \%}$ \\
\hline Total & $\mathbf{1 0 0 \%}$ & $\mathbf{1 0 0 \%}$ & $\mathbf{4 6 5 :} \mathbf{1 0 0 \%}$ & $\mathbf{1 0 0 \%}$ & $\mathbf{1 0 0 \%}$ & $\mathbf{1 0 0 \%}$ \\
\hline
\end{tabular}

$* \mathrm{p}<0.05$

Respondents were asked to indicate their respective level of education based on five categories. Table 4.1 shows that most of the WC respondents (37.2\%) had completed Grade 12, followed by those who had completed a diploma (35.9\%), a degree (21.9\%), below Grade $12(1.8 \%)$, and a postgraduate qualification (2.8\%). Gender was cross-tabulated in order to establish any significant difference between male and female owners. In order to facilitate the analysis, education levels were collapsed into two categories; namely, "educated" (post-Grade 12 qualification) and "not well educated" (Grade 12 and below), as per Table 4.2. 
Table 4.1: Educational Level

\begin{tabular}{|l|c|c|c|c|}
\hline \multirow{2}{*}{} & \multicolumn{2}{|c|}{ WC } & \multicolumn{2}{c|}{ KZN } \\
\cline { 2 - 5 } & Frequency & Percent & Frequency & Percent \\
\hline Primary School (Grades 1 - 7) & 2 & $0.4 \%$ & 18 & $6.4 \%$ \\
\hline Secondary School (Grades 8-10) & 8 & $1.8 \%$ & 67 & $23.8 \%$ \\
\hline Senior Secondary School (Grades 11 - 12) & 170 & $37.2 \%$ & 103 & $36.5 \%$ \\
\hline Diploma (3 years or more) & 164 & $35.9 \%$ & 56 & $19.9 \%$ \\
\hline Graduate (Degree) & 100 & $21.9 \%$ & 29 & $10.3 \%$ \\
\hline Postgraduate & 13 & $2.8 \%$ & 9 & $3.2 \%$ \\
\hline Total & 465 & $100.0 \%$ & 465 & $100.0 \%$ \\
\hline
\end{tabular}

As noted in Table 4.2, 64.6\% of WC respondents were educated. There were no significant differences between males and females, implying that male and female entrepreneurs were equally educated in both provinces. WC had a higher percentage of business owners that were educated.

Table 4.2: Gender and Education

\begin{tabular}{|l|c|c|c|c|c|c|}
\hline & \multicolumn{3}{|c|}{ WC } & \multicolumn{3}{c|}{ KZN } \\
\hline & Not Well Educated & Educated & Total & Not Well Educated & Educated & Total \\
\hline Male & $35.4 \%$ & $64.6 \%$ & $100.0 \%$ & $68.5 \%$ & $31.5 \%$ & $100.0 \%$ \\
\hline Female & $38.9 \%$ & $61.1 \%$ & $100.0 \%$ & $61.2 \%$ & $38.8 \%$ & $100.0 \%$ \\
\hline Total & $36.4 \%$ & $63.6 \%$ & $100.0 \%$ & $66.7 \%$ & $33.3 \%$ & $100.0 \%$ \\
\hline
\end{tabular}

$* \mathrm{p}<0.05$

\section{Gender and Growth}

Respondents were asked to indicate whether the number of employees in their business had changed over the past two years. For WC, $71.3 \%$ of respondents indicated that their labour force had expanded, whilst this figure was lower for KZN, as shown in Table 5.

Table 5: Gender and Labour Growth

\begin{tabular}{|c|c|c|c|c|c|c|c|c|}
\hline \multirow{3}{*}{$\begin{array}{c}\text { Gende } \\
\mathbf{r}\end{array}$} & \multicolumn{4}{|c|}{ WC } & \multicolumn{4}{|c|}{ KZN } \\
\hline & \multicolumn{3}{|c|}{$\begin{array}{l}\text { Over the past two years, has your } \\
\text { labour force: }\end{array}$} & \multirow{2}{*}{ Total } & \multicolumn{3}{|c|}{$\begin{array}{l}\text { Over the past two years, has your } \\
\text { labour force: }\end{array}$} & \multirow{2}{*}{ Total } \\
\hline & Expanded & Contracted & $\begin{array}{c}\text { Not } \\
\text { Changed }\end{array}$ & & Expanded & Contracted & $\begin{array}{c}\text { Not } \\
\text { changed }\end{array}$ & \\
\hline Male & $50.2 \%$ & $4.7 \%$ & $15.3 \%$ & $70.3 \%$ & $28.7 \%$ & $15.9 \%$ & $21.8 \%$ & $66.4 \%$ \\
\hline Female & $21.1 \%$ & $1.5 \%$ & $7.1 \%$ & $29.7 \%$ & $19.2 \%$ & $7.3 \%$ & $7.0 \%$ & $33.6 \%$ \\
\hline Total & $71.3 \%$ & $6.3 \%$ & $22.4 \%$ & $100.0 \%$ & $47.9 \%$ & $23.2 \%$ & $28.8 \%$ & $100.0 \%$ \\
\hline
\end{tabular}

$* \mathrm{p}<0.05$ two years.

Respondents were also asked to indicate whether they had seen an increase in labour and sales over the past

Table 6 shows that the majority $(84.7 \%)$ of WC businesses had seen an increase in turnover. In KZN, turnover growth was lower, with $71.7 \%$ of male and female business owners reporting increases.

Table 6: Gender and Turnover

\begin{tabular}{|c|c|c|c|c|c|c|}
\hline \multirow{3}{*}{ Gender } & \multicolumn{3}{|c|}{ WC } & \multicolumn{3}{|c|}{$\mathbf{K Z N}$} \\
\hline & \multicolumn{2}{|c|}{$\begin{array}{l}\text { Q6. Business development in terms of } \\
\text { increased turnover }\end{array}$} & \multirow[t]{2}{*}{ Total } & \multicolumn{2}{|c|}{$\begin{array}{c}\text { Q6. Business development in terms of } \\
\text { increased turnover }\end{array}$} & \multirow[t]{2}{*}{ Total } \\
\hline & Yes & No & & Yes & No & \\
\hline Male & $59.7 \%$ & $10.8 \%$ & $70.5 \%$ & $47.6 \%$ & $18.8 \%$ & $66.4 \%$ \\
\hline Female & $25.0 \%$ & $4.5 \%$ & $29.5 \%$ & $24.1 \%$ & $9.5 \%$ & $33.6 \%$ \\
\hline Total & $84.7 \%$ & $15.3 \%$ & $100.0 \%$ & $71.7 \%$ & 28.3 & $100.0 \%$ \\
\hline
\end{tabular}

$* \mathrm{p}<0.05$ 


\section{Education and Business Growth}

Education was cross-tabulated with labour growth to establish any association between these two variables. From Table 7.1, it is noted that a higher proportion (71.9\% of those respondents indicating that their business had expanded in terms of labour force growth) were educated. The results show an association (p < 0:05) between education and increase in labour force, implying a positive relationship between labour growth and education.

Table 7.1: Education and Labour Force Growth

\begin{tabular}{|c|c|c|c|c|c|c|c|c|}
\hline \multirow[b]{3}{*}{ Education } & \multicolumn{4}{|c|}{ WC } & \multicolumn{4}{|c|}{ KZN } \\
\hline & \multicolumn{3}{|c|}{$\begin{array}{l}\text { Over the past two years, has your } \\
\text { labour force: }\end{array}$} & \multirow{2}{*}{ Total } & \multicolumn{3}{|c|}{$\begin{array}{l}\text { Over the past two years, has your } \\
\text { labour force: }\end{array}$} & \multirow{2}{*}{ Total } \\
\hline & Expanded & Contracted & $\begin{array}{c}\text { Not } \\
\text { Changed }\end{array}$ & & Expanded & Contracted & $\begin{array}{c}\text { Not } \\
\text { changed }\end{array}$ & \\
\hline Not educated & $23.5 \%$ & $3.5 \%$ & $12.6 \%$ & $39.6 \%$ & $27.5 \%$ & $16.4 \%$ & $22.4 \%$ & $66.4 \%$ \\
\hline Educated & $48.5 \%$ & $2.9 \%$ & $9.1 \%$ & $60.4 \%$ & $20.4 \%$ & $6.8 \%$ & $6.4 \%$ & $33.6 \%$ \\
\hline Total & $71.9 \%$ & $6.4 \%$ & $21.7 \%$ & $100.0 \%$ & $47.9 \%$ & $23.2 \%$ & $28.8 \%$ & $100.0 \%$ \\
\hline
\end{tabular}

$* \mathrm{p}<0.05$

Table 7.2 cross-tabulates education and turnover. A higher proportion of educated respondents indicated an increase in turnover. This further supports the assertion that education can be associated with business growth (in terms of turnover). In WC, 53.8\% of educated and 30.8\% of not educated respondents indicated an increase in turnover in the two years preceding the study. A total of $71.7 \%$ of KZN respondents (both educated and not educated) reported an increase in turnover during the same two years preceding the study.

Table 7.2: Education and Turnover

\begin{tabular}{|c|c|c|c|c|c|c|}
\hline \multirow{3}{*}{$\begin{array}{c}\text { Educational } \\
\text { Level }\end{array}$} & \multicolumn{3}{|c|}{ WC } & \multicolumn{3}{|c|}{ KZN } \\
\hline & \multicolumn{2}{|c|}{$\begin{array}{l}\text { Business development in terms of } \\
\text { increased turnover }\end{array}$} & \multirow[t]{2}{*}{ Total } & \multicolumn{2}{|c|}{$\begin{array}{l}\text { Business development in terms of } \\
\text { increased turnover }\end{array}$} & \multirow{2}{*}{$\begin{array}{c}\text { Total } \\
\text { Yes }\end{array}$} \\
\hline & Yes & No & & Yes & No & \\
\hline Not educated & $30.8 \%$ & $8.6 \%$ & $39.4 \%$ & $44.8 \%$ & $22.2 \%$ & $67.0 \%$ \\
\hline Educated & $53.8 \%$ & $6.9 \%$ & $60.6 \%$ & $26.8 \%$ & $6.1 \%$ & $33.0 \%$ \\
\hline Total & $84.5 \%$ & $15.5 \%$ & $100.0 \%$ & $71.70 \%$ & $28.30 \%$ & $100.00 \%$ \\
\hline
\end{tabular}

$* \mathrm{p}<0.05$

Table 8.1 shows that across both provinces of $\mathrm{WC}$ and $\mathrm{KZN}$, respondents reported an increase in labour growth in the two years preceding the study. The expansion in WC (71.4\%) was, however, much more significant than in KZN (47.9\%). KZN respondents also reported a greater incidence of business contraction (23.2\%) as opposed to $\mathrm{WC}$ respondents $(6.2 \%)$.

Table 8.1 Labour Force

\begin{tabular}{|l|c|c|c|c|}
\hline \multirow{2}{*}{} & \multicolumn{2}{|c|}{ WC } & \multicolumn{2}{c|}{ KZN } \\
\cline { 2 - 5 } & Frequency & Percent & Frequency & Percent \\
\hline Expanded & 332 & $71.4 \%$ & 222 & $47.9 \%$ \\
\hline Contracted & 29 & $6.2 \%$ & 108 & $23.2 \%$ \\
\hline Not Changed & 104 & $22.4 \%$ & 135 & $28.9 \%$ \\
\hline Total & $\mathbf{4 6 5}$ & $\mathbf{1 0 0 . 0 \%}$ & $\mathbf{4 6 5}$ & $\mathbf{1 0 0 . 0 \%}$ \\
\hline
\end{tabular}

From Table 8.2 , it can be seen that $84.7 \%$ of WC respondents reported that their respective businesses had experienced growth in terms of turnover, whilst $15.3 \%$ indicated that their respective businesses had experienced a decrease in turnover. A total of $71.7 \%$ of KZN respondents indicated that their businesses had experienced an increase in turnover, as opposed to $28.3 \%$ reporting a decline in turnover in the two-year period preceding the study. 
Table 8.2 Increase in Turnover

\begin{tabular}{|l|c|c|c|c|}
\hline \multirow{2}{*}{} & \multicolumn{2}{|c|}{ WC } & \multicolumn{2}{c|}{ KZN } \\
\cline { 2 - 5 } & Frequency & Percent & Frequency & Percent \\
\hline Yes & 393 & $84.7 \%$ & 334 & $71.7 \%$ \\
\hline No & 71 & $15.3 \%$ & 131 & $28.3 \%$ \\
\hline Total & 465 & $100.0 \%$ & 465 & $100.0 \%$ \\
\hline
\end{tabular}

\section{DISCUSSION}

Based on the findings above, successful performance by women in business is mainly thanks to them having equal accessibility to resources, such as financial, as well as reduced social constraints in terms of their competencies and a social tendency that encourages women to pursue higher education. According to Ahl (2006), liberal feminist theory suggests that there should be no difference in the performance of female-owned and maleowned business, provided females are not discriminated against in terms of their access to resources such as finance and education.

Until recently in South Africa, it was accepted that male entrepreneurs were more likely than females to have education and experience with business or managerial skills. This trend has fortunately changed, however, and as the findings indicate, women are now reaching similar levels. Moreover, women's choice of industry and business size might actually be linked to differences in business objectives. It may be argued that compared to men, women are less motivated by growth and profits and more motivated by internal goals, such as personal accomplishment and independence. Some studies (Carter \& Williams, 2003; Menzies, Diochon, \& Gasse, 2004) have found women to have weaker business backgrounds than men, including a lack of relevant education and business experience; however, this South African study found this to be untrue. However, it should be mentioned that the evidence on poor entrepreneurial performance amongst women is not undisputed. A study conducted many years ago by Westhead, Storey, and Cowling (1995) found similar survival and growth rates for male-owned and female-owned businesses. Finally, the current literature does not clearly reveal whether gender-based performance differences in SMMEs are mainly attributable to voluntary choices by women entrepreneurs or due to constraints.

\section{CONCLUSION}

This article intended to establish whether education and gender are associated with business growth. The study found that $66 \%$ of business owners interviewed had a post-Grade 12 qualification. There were no significant differences found between gender and education and between gender and growth. However, it was found that education is associated with business growth, with labour force growth and turnover being used as growth variables. In addition, gender does matter when it comes to perceptions of barriers to entrepreneurship and their relationship with entrepreneurial intentions. The role of gender and education is not consistent. The South African government should promote entrepreneurship, in general, and female entrepreneurship, in particular, while creating support mechanisms that offer advice and training and which provide access to finance and networks. In comparison, the educational systems in place in countries such as Belgium and China help to explain the non-significant gender differences in the perceived importance of the barrier constituted by lack of competency. Higher education in such countries is not as costly as in First World or developed countries. Many Belgian and Chinese students do not work while studying, leaving them with less work experience and subsequently shaping both male and female perceptions of competency and entrepreneurial intentions.

The assertion that women in business are at a disadvantage compared to their counterparts is a common theme in discussions of SMMEs and company growth. Research has frequently pointed out the various barriers that women face in the world of SMMEs, including biased social practices, educational challenges, expected family roles, and difficulty in forming strategic alliances with business contacts. In light of the proliferation of accepted information in the SMME literature, these assumptions have seldom been subjected to rigorous investigation and only a few carefully designed studies have compared the performance of SMMEs headed by men and those headed by women. The findings of this study critically question the conventional wisdom regarding women's inferiority in SMMEs. Moreover, it was found that in South Africa, the processes underlying SMME performance are similar, irrespective of an entrepreneur's education, age and gender. 


\section{AUTHOR INFORMATION}

Ricardo Peters (PhD) is an accomplished academic leader and currently heads the fastest growing business school in South Africa. He has experience from both the corporate world and in academia. His area of research is economic development from an SMME perspective. Ricardo Peters also teaches investments, financial planning, management and entrepreneurship. His passion for community transformation has resulted in him initiating sustainable development programmes in disadvantaged communities in Cape Town. E-mail: rmpeters@uwc.ac.za (Corresponding author)

Garth van Gensen (PhD). Prior to joining the School for Business and Finance (SBF) at the University of the Western Cape (UWC), Dr. van Gensen was the Chief Executive Officer (CEO) of the Nelson Mandela Metropolitan University (NMMU), where his main focus had been on the advancement of the NMMU. He has gained extensive industry experience, especially in the field of marketing when he was the regional manager of a national and wellknown short term insurance brokering company. He is also the founder of Garth van Gensen Consultancy, which concerns itself with the advancement of higher education and monitoring and evaluating of private funding. E-mail: gvangensen@uwc.ac.za

Eslyn Isaacs (M.Com) completed a Masters in Commerce at the University of the Western Cape. He teaches underand post graduate students in marketing, services marketing and general management. His research focus is small business management and Entrepreneurship. E-mail: eisaacs@uwc.ac.za

Mark Botha (M.Com) is a lecturer in the Finance Department at UWC. He is also the head of Post Graduate studies in the SBF. His research interest includes Entrepreneurship and Maritime studies. E-mail: mbotha@uwc.ac.za

Visvanathan Naicker (PhD) is a Professor in the School of Business Leadership at UNISA's Graduate School of Business Leadership. Prior to joining UNISA, he has been lecturing at the University of the Western Cape in the Management department for 6 years after spending 22 years in information systems in the corporate sector. He was also HOD of the masters and doctoral research within the Management Department in the School of Business and Finance. He is also a reviewer of 5 high impact journals, examiner and supervisor of masters \& doctoral students. Prof Naicker is widely published in information systems, strategic information systems and has secondary interests in computers and education. E-mail: naickv@unisa.ac.za

\section{REFERENCES}

1. Acs, Z. J., Arenius, P., Hay, M., \& Minniti, M. (2005). Global entrepreneurship monitor: 2004 executive report. Retrieved 7 September 2006 from http://www.gemconsortium.org

2. Ahl, H. (2006). Why research on women entrepreneurs needs new directions. Entrepreneurship Theory and Practice, 30(5), 595-621.

3. Alsos, G. A., Isaksen, E. J., \& Ljunggren, E. (2006). New venture financing and subsequent business growth in men- and women-led businesses. Entrepreneurship Theory and Practice, 30(5), 667-686.

4. Ang, J. S. (1992). On the theory of finance for privately held firms. Journal of Small Business Finance, l(3), 185-203.

5. Arenius, P., \& Minniti, M. (2005). Perceptual variables and nascent entrepreneurship. Small Business Economics, 24(3), 233-247.

6. Barringer, B. R., Jones, F. F., \& Neubaum, D. O. (2005). A quantitative content analysis of the characteristics of rapid-growth firms and their founders. Journal of Business Venturing, 20(5), 663-687.

7. Belcourt, M., Burke, R., \& Lee-Gosselin, H. (1991). From the frying pan into the fire: Exploring entrepreneurship as a solution to the glass ceiling. Journal of Small Business and Entrepreneurship, 8(3), 49-55.

8. Belenky, M. F., Clinchy, B. M., Goldberger, N. R., \& Tarule, J. M. (1986). Women's ways of knowing. New York, NY: Basic Books Inc.

9. Berger, A. N., \& Udell, G. F. (2006). A more complete conceptual framework for SME finance. Journal of Banking and Finance, 30(11), 2945-2966. 
10. Bird, B., \& Jelinek, M. (1988). The operation of entrepreneurial intentions. Entrepreneurship Theory and Practice, 13(2), 21-29.

11. Blanchflower, D. G., \& Oswald, A. J. (2004). Well-being over time in Britain and the USA. Journal of Public Economics, 88(7), 1359-1386.

12. Brush, C. G. (1992). Research on women business owners: Past trends, a new perspective and future directions. Entrepreneurship Theory and Practice, 16(4), 5-30.

13. Brush, C. G. (1997). Women-owned businesses: Obstacles and opportunities. Journal of Developmental Entrepreneurship, 2, 1-24.

14. Brush, C. G., Carter, N. M., Gatewood, E., Greene, P., \& Hart, M. (2004a). Clearing the hurdles: Women building high-growth businesses. Upper Saddle River, NJ: FT Press.

15. Brush, C. G., Carter, N. M., Gatewood, E., Greene, P., \& Hart, M. (2004b). Gatekeepers of venture growth: A Diana Project report on the role and participation of women in the venture capital industry. Kansas City, MO: Kauffman Foundation.

16. Carter, N. M., \& Allen, K. R. (1997). Size determinants of women-owned businesses: Choice or barriers to resources? Entrepreneurship and Regional Development, 9, 211-220.

17. Carter, N. M., \& Williams, M. L. (2003). Comparing social feminism and liberal feminism: The case of new firm growth. In: J.E. Butler (Ed.), New perspectives on women entrepreneurs (pp. 25-50). Greenwich, CT: Information Age Publishing.

18. Carter, S. (2000). Gender and enterprise. Enterprise and small business: Principles, practice and policy (pp. 166-181). Harlow: Prentice Hall/Pearson Education Ltd.

19. Carter, S., Shaw, E., Wilson, F., \& Lam, W. (2006). Gender, entrepreneurship and business finance: Investigating the relationship between banks and entrepreneurs in the UK. In: C. G. Brush, N. M. Carter, E. J. Gatewood, P. G. Greene \& M. M. Hart (Eds.). Growth-oriented women entrepreneurs and their businesses: A global research perspective (pp. 373-392). Cheltenham: Edward Elgar.

20. Carter, S., \& Rosa, P. (1998). The financing of male- and female owned businesses. Entrepreneurship and Regional Development, 10(3), 225-242.

21. Catley, S., \& Hamilton, R. T. (1998). Small business development and gender of owner. Journal of Management Development, 17(1), 75-82.

22. Chaganti, R. (1986). Management in women-owned enterprises. Journal of Small Business Management, 24(4), 18-29.

23. Chalera, C. S. (2007). An impact analysis of South Africa's national strategy for the development and promotion of SMMEs. (PhD Thesis). Pretoria: University of Pretoria.

24. Cliff, J. E. (1998). Does one size fit all? Exploring the relationship between attitudes towards growth, gender, and business size. Journal of Business Venturing, 13(6), 523-542.

25. Cooper, A. C. (1993). Challenges in predicting new firm performance. Journal of Business Venturing, 8(3), 241-253.

26. Cooper, A. C., Gimeno-Gascon, F. J., \& Woo, C. Y. (1994). Initial human and financial capital as predictors of new venture performance. Journal of Business Venturing, 9(5), 371-395.

27. Curran, J., Bolton, J. E., \& Britain, G. (1986). Bolton fifteen years on: A review and analysis in Britain 1971-1986. Milton Keynes: Small Business Research Trust.

28. De Bruin, A., Brush, C. G., \& Welter, F. (2006). Introduction to the special issue: Towards building cumulative knowledge on women's entrepreneurship. Entrepreneurship Theory and Practice, 30, 585-592.

29. De Jong, J. P. J., \& Vermeulen, P. A. M. (2006). Determinants of product innovation in small firms: A comparison across industries. International Small Business Journal, 24(6), 587-609.

30. Delmar, F., Davidsson, P., \& Gartner, W. B. (2003). Arriving at the high-growth firm. Journal of Business Venturing, 18(2), 189-216.

31. DTI (Department of Trade and Industry). (1995). White Paper on National Strategy for the Development and Promotion of Small Business in South Africa. Pretoria: Government Printing Works.

32. Fabowale, L., Orser, B., \& Riding, A. (1994). Gender, structural factors, and credit terms between Canadian small businesses and financial institutions. Toronto: Ryerson Polytechnic University.

33. Fenske, J. (2004). Fact sheet: Poverty in South Africa. Pretoria: Human Sciences Research Council, p. 5.

34. Fischer, E. M., Reuber, A. R., \& Dyke, L. S. (1993). A theoretical overview and extension of research on sex, gender, and entrepreneurship. Journal of Business Venturing, 8(2), 151-168. 
35. Garnsey, E., Stam, E., \& Heffernan, P. (2006). New firm growth: Exploring processes and paths. Industry and Innovation, 13(1), 1-20.

36. Gatewood, E. J., Carter, N. M., Brush, C. G., Greene, P. G., \& Hart, M. M. (2003). Women entrepreneurs, their ventures, and the venture capital industry: An annotated bibliography. Stockholm: ESBRI.

37. Goffee, R., \& Scase, R. (1985). Women in charge: The experiences of female entrepreneurs. London: Allen and Unwin.

38. Ghosh, J. (2002). Globalization, export-oriented employment for women and social policy: A case study of India. Social Scientist, 30(11/12), 17-60.

39. Gurol, Y., \& Atsan, N. (2006). Entrepreneurial characteristics amongst university students: Some insights for entrepreneurship education and training in Turkey. Education + Training, 48(1), 25-38.

40. Guzman, J. (1994). Towards a taxonomy of entrepreneurial theories. International Small Business Journal, 12(4), 77-88.

41. Guzman, J., \& Santos, F. J. (2001). The booster function and the entrepreneurial quality: An application to the province of Seville. Entrepreneurship and Regional Development, 13(3), 211-228.

42. Isaksen, E., \& Kolvereid, L. (2005). Growth objectives in Norwegian start-up businesses. International Journal of Entrepreneurship and Small Business, 2(1), 17-26.

43. Jackson, P. L. M. (2004). Entrepreneurial support in South Africa: A case study of a small enterprise support centre in Johannesburg. Birmingham: University of Birmingham.

44. Jarvis, R. (2000). Finance and the small firm. In: S. Carter \& D. Jones-Evans (Eds.), Enterprise and small business: Principles, practice and policy. London: FT Prentice Hall.

45. Kalleberg, A. L. \& Leicht, K. T. (1991). Gender and organizational performance: Determinants of small business survival and success. Academy of Management Journal, 34(1), 136-161.

46. Kaplan, E. (1988). Women entrepreneurs: Constructing a framework to examine venture success and failure. In: B. A. Kirchhoff, W. A. Long, W. E. McMullan, K. H. Vesper \& W. E. Wetzel Jr. (Eds.), Frontiers of entrepreneurial research (pp. 643-653). Boston, MA: Babson College.

47. Kesper, A. (2001). Failing or not aiming to grow? Manufacturing SMMEs and their contribution to employment growth in South Africa. Urban Forum, 12, 171-203.

48. Kirstein, A. (2006). The second economy: What it is, and what is needed to meet the growth and development challenges it presents? Address by President Thabo Mbeki to the National Council of Provinces. Available at: http://www.sapu.org.za/documents.

49. Kolvereid, L. (1992). Growth aspirations among Norwegian entrepreneurs. Journal of Business Venturing, 7(3), 209-222.

50. Lee-Gosselin, H., \& Grisé, J. (1990). Are women owner-managers challenging our definitions of entrepreneurship? An in-depth survey. Journal of Business Ethics, 9(4), 423-433.

51. Marlow, S., \& Patton, D. (2005). All credit to men? Entrepreneurship, finance, and gender. Entrepreneurship Theory and Practice, 29(6), 717-735.

52. Menzies, T., Diochon, M., \& Gasse, Y. (2004). Examining venture-related myths concerning women entrepreneurs. Journal of Developmental Entrepreneurship, 9(2), 89-107.

53. Moreno, A. M., \& Casillas, J. C. (2007). High-growth SMEs versus non-high-growth SMEs: A discriminant analysis. Entrepreneurship and Regional Development, 19(1), 69-88.

54. Morris, M. H., Miyasaki, N. N., Watters, C. E., \& Coombes, S. M. (2006). The dilemma of growth: Understanding venture size choices of women entrepreneurs. Journal of Small Business Management, 44(2), 221-244.

55. Ogujiuba, K. K., Ohuche, F. K., \& Adenuga, A. O. (2004). Credit availability to small and medium scale enterprises in Nigeria: Importance of new capital base for banks - background and issues. Retrieved from http://www.ideas.repec.org/p/wpa/wuwpma/0411002.html

56. Peters, R. M. (2009). SMME development initiatives and its constraints to growth in South Africa. (DCom Thesis). Johannesburg: University of Johannesburg.

57. Radipere, S., \& Van Scheers, L. (2005). Investigating whether a lack of marketing and managerial skills is the main cause of business failure in South Africa. South African Journal of Economic and Management Sciences, 8(4), 402.

58. Reynolds, P. D., Bygrave, W. D., Autio, E., Cox, L. W., \& Hay, M. (2003). Global Entrepreneurship Monitor (GEM): Executive Report. Boston, MA: Babson College. 
59. Reynolds, W., Williams, A. J., \& Savage, W. (1994). Your own business: A practical guide to success. Melbourne: Thomas Nelson Australia.

60. RSA (Republic of South Africa). (1996). Growth, employment and reconstruction strategy. Pretoria: Government Printing Works.

61. Scarborough, N. M., \& Zimmerer, T. W. (1996). Effective small business management (5th Ed.). Upper Saddle River, NJ: Prentice Hall.

62. Scott, M., \& Gibb, A. A. (1986). Understanding small firm growth. In M. Scott, A. A. Gibb, J. Lewis, \& T. Faulkner (Eds.), Small firm growth and development (pp. 81-104). Hampshire: Gower.

63. Sheppard, D. A., Douglas, E. J., \& Shanley, M. (2000). Ignorance, external shocks, and risk reduction strategies. Journal of Business Venturing, 15(5-6), 393-410.

64. Stats SA (Statistics South Africa). (2012). Quarterly Labour Force Survey (QLFS): P0212. Retrieved from http://www.statssa.gov.za/publications/publicationbrowse.asp

65. Stoner, C. R., Hartman, R. I., \& Arora, R. (1990). Work-home role conflict in female owners of small businesses: An exploratory study. Journal of Small Business Management, 28(1), 30-38.

66. Vos, E., Yeh, A. J. Y., Carter, S., \& Tagg, S. (2007). The happy story of small business financing. Journal of Banking and Finance, 31(9), 2648-2672.

67. Wattanapruttipaisan, T. (2003). Four proposals for improved financing of SME development in ASEAN. Asian Development Review, 20(2), 66-104.

68. Welter, F. (2006). Women entrepreneurship in Germany: State of the art, progress and open questions. In: C. G. Brush, N. M. Carter, E. J. Gatewood, P. G. Greene, \& M. M. Hart (Eds.), Growth-oriented women entrepreneurs and their businesses: A global research perspective (pp. 128-153). Cheltenham: Edward Elgar.

69. Westhead, P., Storey, D., \& Cowling, M. (1995). An exploratory analysis of the factors associated with the survival of independent high-technology firms in Great Britain. In F. Chittenden, M. Robertson, \& I. Marshall (Eds.), Small firms: Partnerships for growth (pp. 63-99). London: Paul Chapman Publishing.

70. Wilson, J. O. S., \& Morris, J. E. (2000). The size and growth of UK manufacturing and service firms. Service Industries Journal, 20(2), 25-38.

71. World Bank. (2006). South Africa: Enhancing the effectiveness of government in promoting micro, small and medium enterprise. Report for the Department of Trade and Industry. Pretoria: Government Printing Works.

72. World Bank. 2008. South Africa: Country in brief. Retrieved from http://siteresources.worldbank.org/ GILDSOUTHAFRICA/insolvency\%20law

73. Yanta, T. (2001). Local government supporting or stunting SMME growth? Indicator South Africa: A Barometer of Social Trends, 18(2), 44-48. 